\title{
الإشتقاق وتعليمها في المفردات
}

\author{
Muhammad Zakki Masykur \\ (r.zack08@gmail.com) \\ (Dosen Intitut Agama Islam Bani Fattah Jombang)
}

\begin{abstract}
الملخصص
الاشتقاق عملية خلق وإبداع في اللغة، وهو رافد هام لها يرفدها بكل ما تحتاج إليه من المفردات والصيخ، إنها عامل من عوامل نمو اللغات وتطورها، ووسيلة رائعة من وسائل إثرائها بالمفردات لتتمكن من التعبير عن مستجدات الحياة من الأفكار والعلوم والفنون. المفردات يسهى بالكلمات، وعي أصغر وحدة لغوية حرة. مثلها كلمة (استعلم) و(يوم) و(إلى). وقد تكون المفردات مجردة وتكون مزبدة. فإن كانت مزبـدة فلها جذر وبها زائدة واحدة أو أكثر. فكلمة (استعلم) جذرهما (علم)، وأما زائدة فيها فهي الهمزة والسين والتاء. والزائدة قد تكون في أول الكلمة فتسمى سابقة، مثل (است) في (استقدم). وقد تكون الزائدة في وسط الكلماة، فتدعى داخلة، مثل الألف في (قادم). وقد تكون الزائدة في آخر الكلماة، مثل (ون) في قادمون، فتدعى حينءذ لاحقة. عادة تعليم المفردات للطلبة الأجنبية يقاس على قدرة الطلبة في ترجما الكلمة وتحديد معنى المفردات ونطقها السليم، واستخدام الكلمة المناسبة في سياق الجملة السليمة. وبعتبر بعض اللغوبين أن حفظ الطلبة للمفردات العربية عملا غير علمي، إذ أربد تقويهم قدرة الطلبة لمعرفة قدرنهم اللغوية على المدرس أن يعد البرنامج يمكن عليهم الاتصال بالعربية وبالتراكيب التي يسيطر عليهم ويستطيع استخدامها بكفاءة كلمات المفتاح: الإشتقاق ، تعليم ، مفردات
\end{abstract}

Derivasi adalah proses pengimbuhan afiks non-inflektif pada dasar untuk membentuk kata. Yang dimaksud dengan derivasi ialah konstruksi yang berbeda distribusinya daripada dasarnya atau afiks yang menghasilkan leksem baru dari leksem dasar. Misalnya kata reviews dapat dianalisis atas sebuah prefiks re-, sebuah akar view, dan sebuah sufiks -s. Prefiks re-membentuk leksem baru review dari bentuk dasar view, sedangkan sufiks $-s$ membentuk kata yang lain dari leksem review. Jadi prefiks re- bersifat derivasi, sedangkan sufiks $-s$ bersifat infleksi. Berdasarkan uraian diatas dapat disimpulkan bahwa derivasi adalah suatu perubahan proses kelas kata (kata kerja) dengan atau tanpa pemindahan kelas kata. Bahasa merupakan alat untuk mengngkapkan makna 
yang diwujudkan melalui kosakata dan tata bahasa. Dengan demikian, kosakata dan tata bahasa berperan sebagai alat pengungkapan makna yang berupa gagasan, pikiran, pendapat dan perasaan. Makna ditentukan oleh lingkup kebahasaan maupun lingkup situasi yang merupakan konsep dasar dalam pendekatan kebermaknaan terhadap pengajaran bahasa yang harus didukung oleh pemahaman lintas budaya. Belajar bahasa asing adalah belajar berkomunikasi melalui bahasa yang dipelajari (bahasa sasaran), baik secara lisan maupun tulisan. Belajar berkomunikasi ini perlu didukung oleh pembelajaran unsur-unsur bahasa tersebut. Dengan kata lain, kebermaknaan bahan pelajaran dan kegiatan pembelajaran memiliki peranan yang amat penting dalam memotivasi siswa untuk mencapai keberhasilan dalam belajar. Pembelajaran mufrodat atau kosa kata merupakan hal yang penting dalam pembelajaran bahasa arab secara umum. Dimana dalam menentukan dan mengukur kemahiran berbahasa tidak terlepas dari kuantitas dan kualitas mufrodat yang dimiliki oleh peserta didik.

Kata kunci: Derivasi, Pembelajaran, Mufradât.

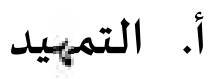

وقد امتازت اللغة العربية عن غيرها من اللغات بأها لغة تصربفية تعتمد على مزايا وخصائص ذاتية في سـ عوزها من ألفاظ المستجدات الحضيارية، وظاهرة الاشتقاق من أهم خصيائص اللغة العريية، ومن أهم الظواهر اللغوية التي اعتمدت عليها في توليد الألفاظ وإنتاجها، ولا تزال هذه الظاهرة صالحة لهذا الغرض في عصرنا الحاضر، إذ لا يزال العلماء والمعجميون يعتبرونها الوسيلة الأولى التي يعتمد عليها من أجل وضع المصطلحات العلمية والتقنية وغيرها، ولا تزال مؤتمرات التعربب، والمؤتمرات التي تعقد حول اللغة العربية والثهوض بها توصي باستخدام هذه الظاهرة والإفادة منها و إنها قوة لنمو اللغة وتكاثر كلمها وتشعب صيغنها. ب. الإشـتقاق ( ) تعر:ف الإشتقاق قال ( في القاموس ) هو أخذ شق الشيء والأخذ في الكلام وفي الخصيومة يمينا وشمالا، وأخذ الكلمة من الكلمةة) انتهى

وفي الاصطلاح أن تجد بين اللفظين تناسبا في المعنى و التركيب فترد أحلهما إلى الآخر ، وقيل هو أن تأخذ من اللفظ ما يناسبـه في التركيب فتجعله دالا على معنى يناسبـه معنى ، وقيل : الأول باعتبار العلم والثاني باعتبار العمل ، وقيل : رد لفظ إلى آخر لموافقتاه إياه في 
حروفه الأصلية ومناسبته له في المعنى. وقيل ما وافق أصلا بحروفه الأصيول ومعنى بتغيير ما

$$
\text { ، وقد نوقش كل واحد من هذه الحدود بمناقشات مدفوعة بدفوعات. }
$$

فاختار الباحث عن تعربف علم الإشتقاق هوعلم باحث عن كيفية خروج الكلم بعضهيا عن بعض بسبب مناسبة بين المخرج والخارج بالأصالة والفرعياة باعتبار جوهرها ، والقيد

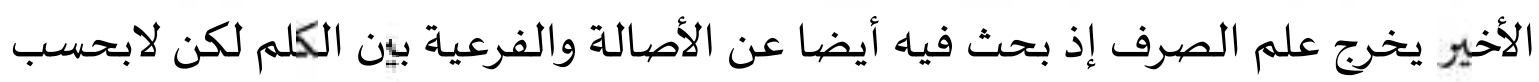

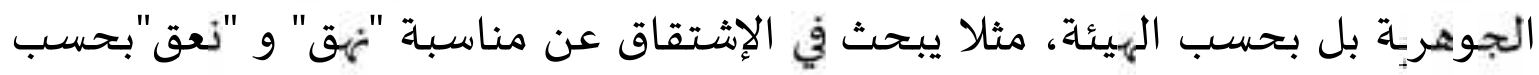

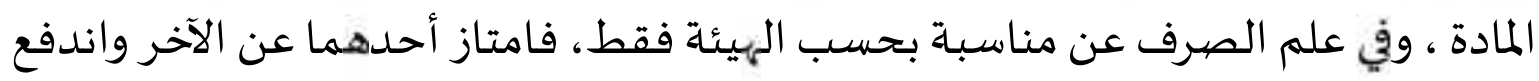
توهم الاتحاد.

الإشتقاق هو أخذ صيغة من أخرى مع اتفاقها معنى ومادة أصلية و هيئة تركيب لها يدل

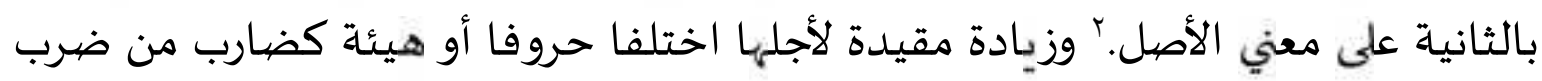

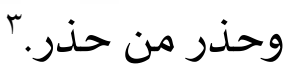
ويعرفه الأستاذ عبد الله أمين بأنه أخذ كلمة من كلمة أوأكثر مع تناسب بين المأخوذة منه في

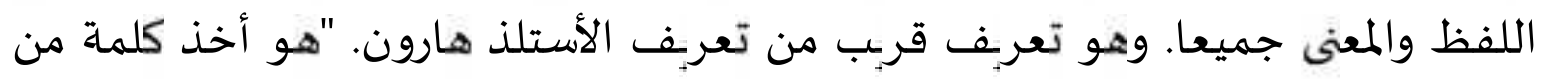

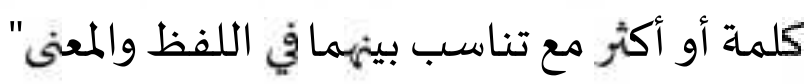
والإشتقاق وسيلة من وسائل نمو اللغة ويتطورها وزيادة ثروة الألفاظ فهها ، وقد اتخذه بعض اللغويين أساسا في تقسيم اللغات إلى فصائل. وقد بين السيوطي التغيرات بين الأصل والمشتق منه والفرع المشتق وحصرها في خمسة

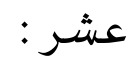
الأول : زبادة حركة - كعلم - وعلم

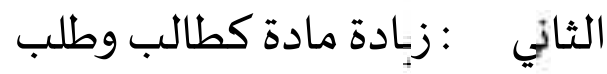

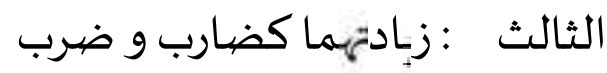
الرابع نقصان حركة كالفرس من الفرس (بتسكين الراء) الخامس : نقصان مادة كثبت وثبات 
السادس : نقصانهما كنزا ونزوان

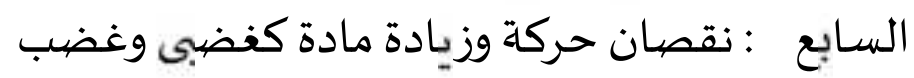
الثامن : نقصان مادة وزيادة حركة كحرم وحرمان التاسع :زبادتهما مع نقصانهما كاستنوق من الناقة العاشر : تغاير الحركتين كبطر بطرا الحادي عشر: نقصان حركة وزيادة أخري وحرف كاضرب من الضربرب الثاني عشر: نقصلن مادة وزيادة أخرى طراضيع من الرضياعة.

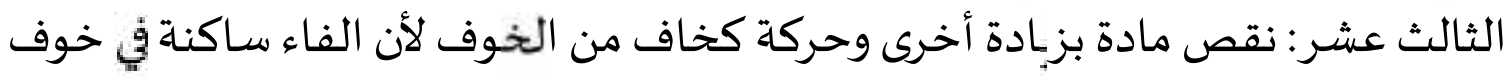
لعدم التركيب. الرابع عشر: نقصيان حركة وحرف وزيادة حركة فقط ، كعد من الوعد، فياء نقصيان الواو وحركتها وزيادة كسرة. الخامس عشر : نقصيان حركة وحرف وزيادة حرف كفاخر من الفخار، نقصت ألف وزادت ألف وفتحة. ؛

\section{r الإشتقاق عند علماء اللغة العربية}

وقد تنبه علماء العربية القدماء إلى فكرة الإشتقاق منذ بدءوا يبحثون في اللغة ، وربطوا بين

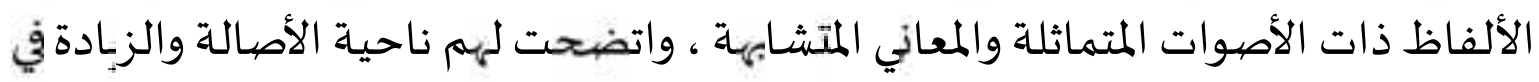

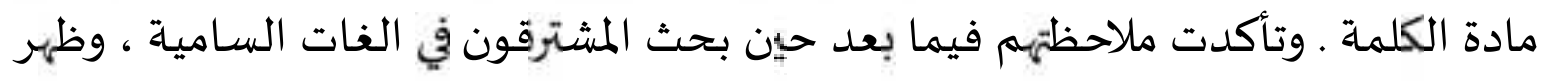
لههم أن الألفاظ السامية تعتمد على جذور أو مواد تعتبر الأصل في كل إشتقاق ، وأن أكثر

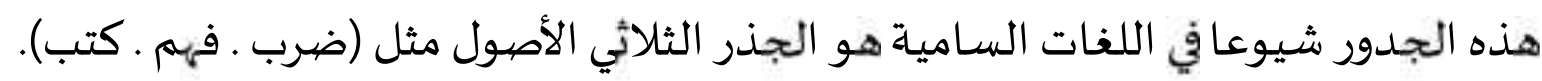
ولم يكد ينتصف القرن الرابع الهجري حتى شهدنا البحث في الإشتقاق يستقر على أمور

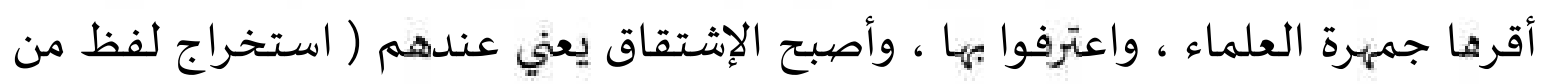

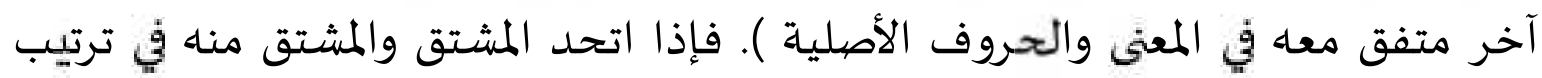
الحروف سمى هذا بالإشتقاق العام ، وإلا فهو الإشتقاق الكبير أو الأكبر. 
وبرجع الفضل في مثل هذا التقييم إلى ابن جني في الخصائص ، وإن لم يطلق على هذه الأنواع تلك المسميات المتعارفة الآن.

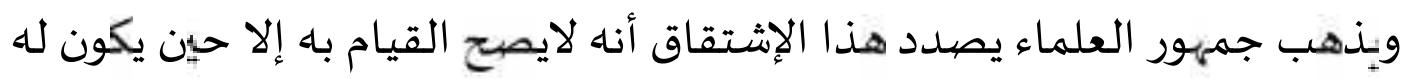
سند من نصوص اللغة يبرهن على أن العرب أصحاب اللغة قد جاءوا بمثله أو نظيره ، وأن

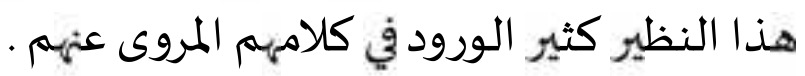
ولما ثبت لدى هؤلاء العلماء أن بعض المشتقات كاسم الفاعل واسم المفعول ونحوهما قد رويت كثيرا في أساليب العرب ، وجاءت من معظم الأفعال ، قالو إن هذا النوع من

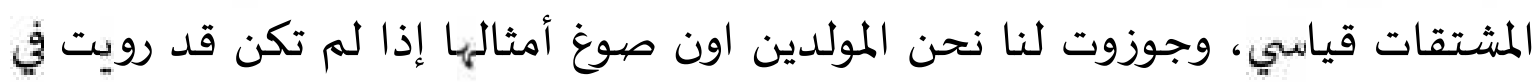

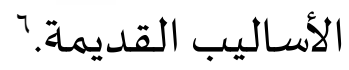

وما أن جاء القرن الثالث الهجري حتى اشتد عوده وقوي ساعده حين بدأ أبو بكر محمد بن الحسن بن دربد بتأليف كتابه (الإشتقاق) وقد حاول فياء أن يرد أسماء قبائل

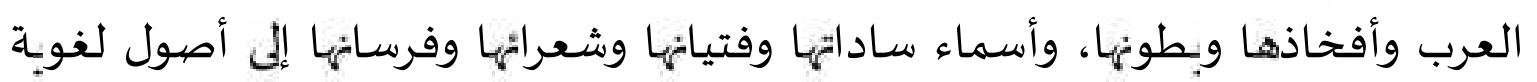
اشتقت منها هذه الأسماء ثم تبعها (أبو الحسين أحمد بن فارس أحداء أئمة اللغة البارزين)

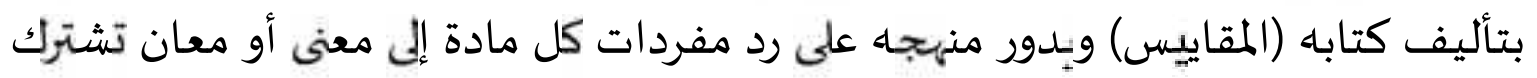
فيها هذه المفردات والكشف عن المعنى الأصلي المشترك في جميع صيغ المادة حيث قال

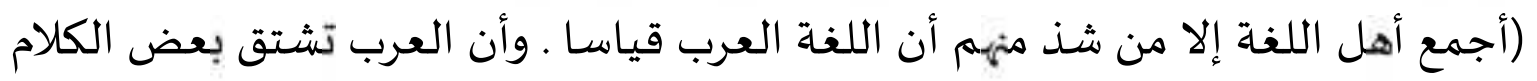
من بعض). ولعل الذي أوحى إليه بفكرة كتابه (المقايسي) هو الإمام "ابن دربد" الذي استهل كتابه

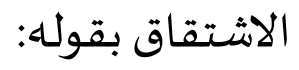
ولم نتعد ذلك إلى اشتقاق أسماء صنوف الناس من نبات الأرض نجمها ويشجرها

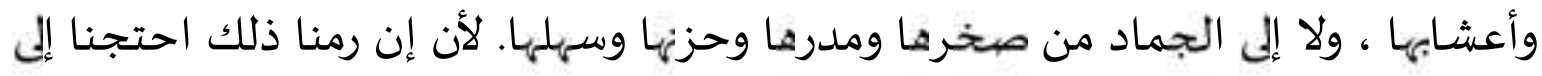
اشتقاق الأصول التي تشتق منها وهذا ما لانهاية له ـ فنهض إلها بما أوتي من غزائر العلم 
وصفاء الذهن وجودة الفكر وجلد البحث، فحاول أن يستكمل صنيع (ابن دربد) فأخرج

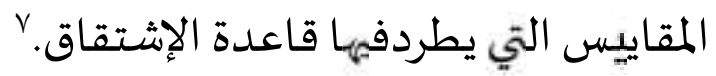

واختار الباحث الآراء وما ان جاء أبو علي الفارمي وتلميذه ابن جني حتى ارتقيا بفن

الإشتقاق خطوات وصعدا باء درجات حين ذشرا قادة الإشتقاق الأكبر والتي تجعل للمادة

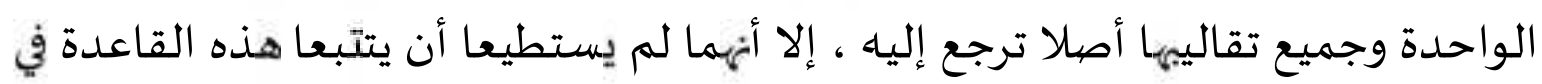
سائر مواد اللغة.

r) الإشتقاق والقياس

قال بعض العلماء : القياس هو النظربة ، والاشتقاق هو التطبيق. والإشتقاق أخذ صيغة

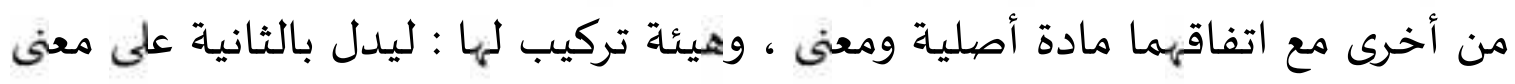

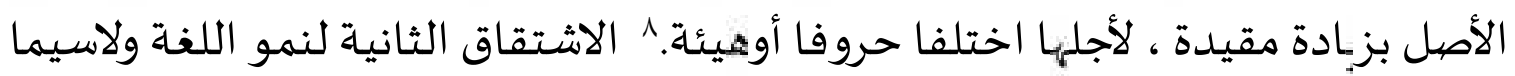

من حيث الألفاظ والصيغ هي ما يسمى بالإشتقاق.

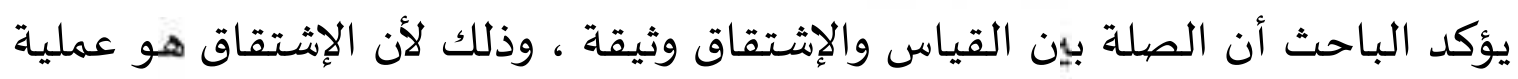

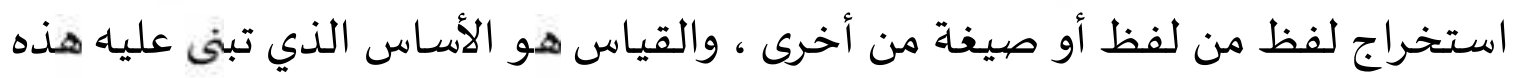
العملية ، هو المبرر الذي تستند عليه مثل العملية الإشتقاقية كي يصبح المشتق مقبولا معترفا باء بين علماء اللغة.

\section{ع) الإشـتقاق والتصريف:}

إذا أمعنا النظر في نصوص الصرفيين رأيناهم لا يفرقون بين التصريف و الإشتقاق،

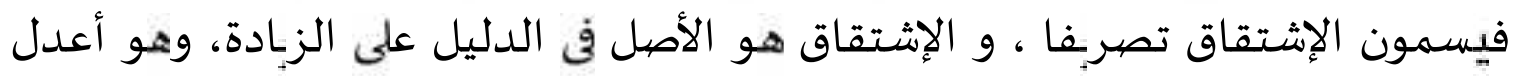

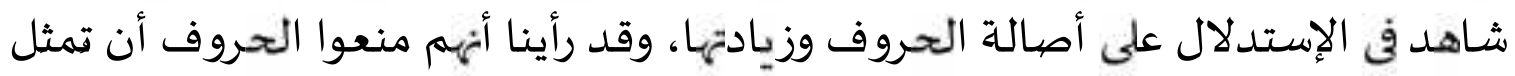
بالفعل ,لانه لا يعرف لها اشتقاق. وقد قال السيرافى فى الإشتقاق: فأما الإشتقاق فهو أن 
ترد عليك الكلمة وفيها بعض حروف الزبادة، فإذا صرفتها سقط ذلك الحرف في بعض تصارفها، فيحكم على الحرف

و ينبغى أن يعلم أن بين التصربف والإشتقاق نسبا قريبا واتصالا شـديدا لأن التصرريف إنما هو أن تجيء إلى الكلمة الواحدة فتصرفها على وجوه شتى وكذلك الك الك

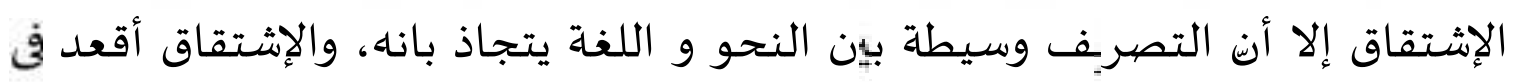
اللغة من التصريف كما أنغ التصربف أقرب إلى النحو من الإشتقاق.

\section{ت. أنواع الإشـتقاق}

يقول ابن جني : الإشتقاق عندي على ضربين كبير وصغير ، فالصغير ما في أيدي الناس وكتهه كأن تأخذ أصلا من الأصيول فتقراه فتجمع بين معانياه وإن اختلفت صيغاء زمعانياه،

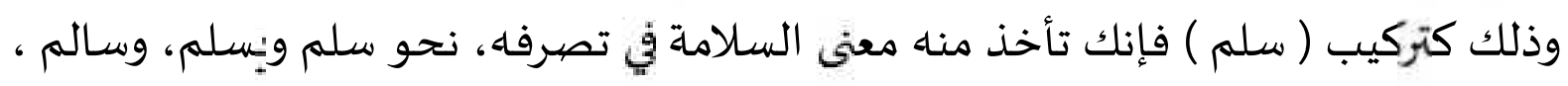

\section{وسلمان وسلمى والسلامة.}

واختار الباحث عن أنواع الاشتقاق عند للأستاذ عبد الله أمين الذي قسم الاشتقاق إلى أربعاة أقسام التي ألفت كتاب الاشتقاق من الدراسات الحديثة. واختلف بين القدماء

$$
\text { والحديث في نوع الاشتقاق الكبار أو النحت. }
$$

ومن الدراسات الحديثة التي ألفت في هذا الفن كتاب الاشتقاق للأستاذ عبد الله أمين

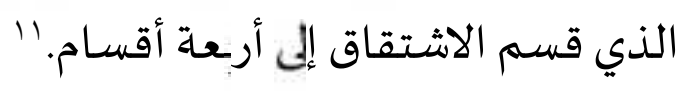

\section{( ) الإشتقاق الصغير (العام)}

أما الإشتقاق العام ، وهو الذي يسمى أحيانا بالاشتقاق الصغير، فهو أن تشتق

$$
\text { من الفعل " فهم" مثلا صيغا أخرى مثل : فاهم ـ مفهوم . تفاهم ... إلخ. }
$$

وليس هناك أي ارتباط عقلي منطقي بين حروف ( الفاء والهاء والميم ) ، وبين المعنى العام الذي يستفاد من تلك الصيغ وهو الإدراك ، وإلا ترتب على هذا أن نتصهور نوعا من الارتباط

$$
10 \text { صديق حسن ................. }
$$


بين حروف العقل "أدرك" وحروف الفعل "فهم"، لأن لكل منها نفس الدلالة ، وهو ما لا يقبله اللغوي الحديث ـ كما يترتب على هذا أن ننكر من اللغة تلك المئات من الكلمات التي اشتركت لفظا واختلفت معانيها اختلافا بينا. وكثير من تلك الصيخ التي يجوز اشتقاقها لا وجود لها فعلا في نص صحيح من نصوص اللغة . فهناك فرق كبير بين ما يجوز لنا اشتقاقه من صيخ ، ومااشتق فعلا

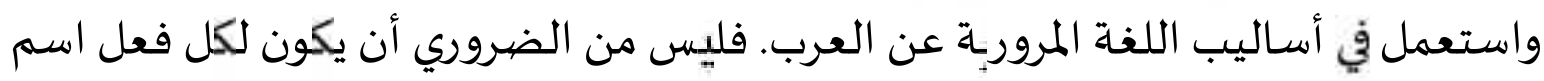
فاعل أو اسم مفعول مرو بين في نصوص اللغة ، فقد لا يحتاج المتكلم أو الكاتب إلى كليهما

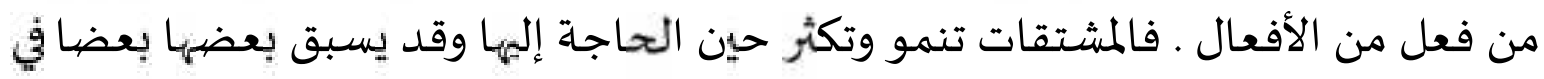

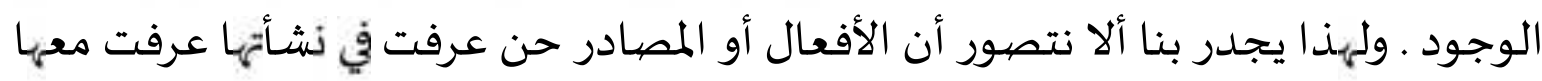

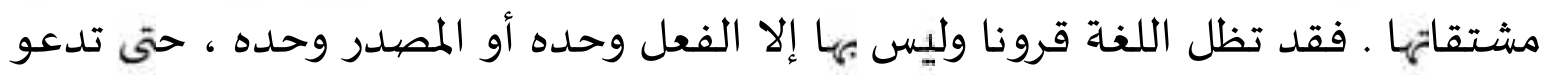
الحاجة إلى ما يشتق منهما. فما يسمي بالإشتقاق العام ليس في الحقيقة إلا نوعا من التوسع في اللغة ما يحتاج إليه

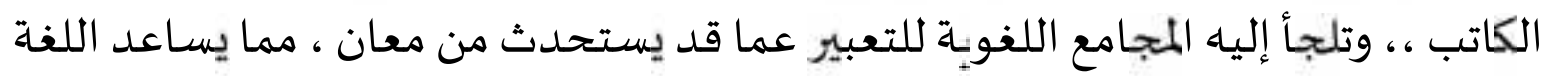
على مسايرة التطور الإجتماعي. وليس مثل الأصوات في هذا النوع من الإشتقاق إلا مثل مواد البناء التي منها قد تؤسس

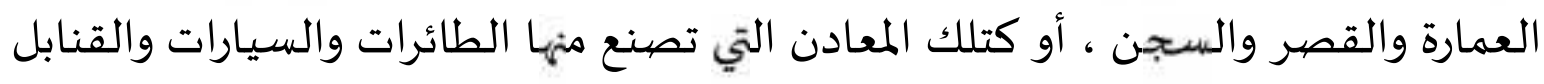

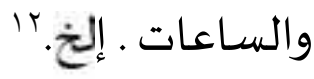
تعربف الإشتقاق الأصفر عند ابن جني : كأن تأخذ أصلا من الأصول فتتقرأه، فتجمع بين معانياه وإن اختلفت صفة ومبانياه وذلك كتركيب (...لم) فإنك تأخذ منها معنى السلامة في تصرفه نحو سلم ويسلم وسلمان وسلمى والسلامة والتسليم....

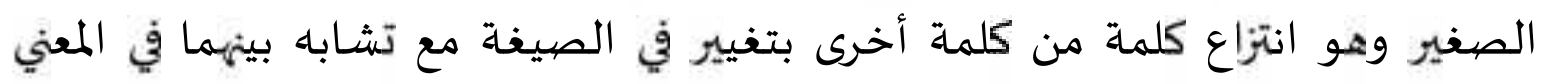

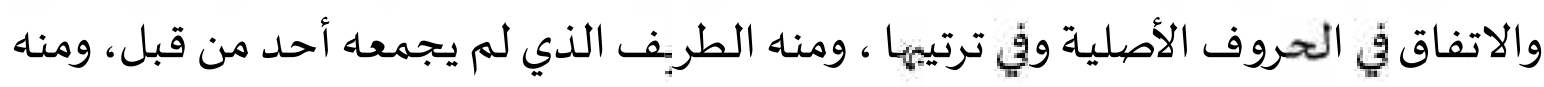
القديم الذائح الذي امتلأت باه كتب النحو والصرف وغيرها كأبنية الأفعال والأسماء وأوز انها والمجرد والمزبد من الأفعال والأسماء واشتقاق الأفعال.

12 إبراهيم أنيس،...................... 
r) ( ب الإشتقاق الأكبر

الإشتقاق الأكبر : أن تأخذ أصلا من الأصيول الثلاثية فتعقد عليه وعلى تقاليبه الستة معنى واحدا تجتمع التراكيب الستة وما يتصرف من كل واحد عليه. ويضرب مثلا لذلك مئك مادة قول ، فيقول "إن معنى (قول) أين وجدت وكيف وقعت من تقدم بعض حروفها على

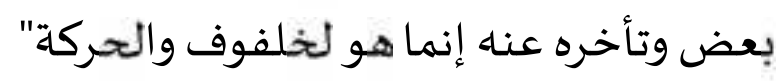

وقد تعرض لهذا النوع بالدراسة التفصيلية ورأيت أن ابن جني قد جانبه الصواب عندما

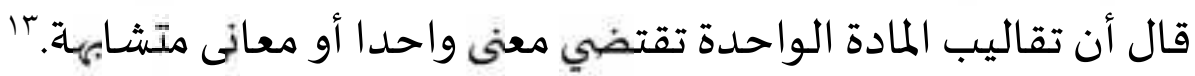

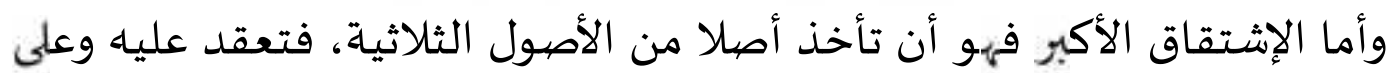
تقاليباء الستتة معنى واحد، تجتمع التراكيب الستاة وما يتصرف من كل واحد منها عليه، وإن تباعد شيء من ذلك عنه رد بلطف الصنعة والتأويل إليه ، كما يفعل الاشتقاقيون ذلك في التراكيب الواحدة. وما وصل إليه ابن فارس وابن جني من نظربتهما الخالدة في فن الاشتقاق هي الذروة التي لم يرتقها أحد بعدهما ، ثم توقف الاجتهاد اللغوي في فن إن فئ الإشتقاق عند صنيعهما، لأن ماصاغاه من نظربتهما ليس مستمرا في جميع اللغة. إلا أن الجهود اللغوية ظلت نشيطة في هذا الفن، وفي تقسيماه وبيان صنوفه وإن كانت لم تتعد صنيع أئمة اللغة الكبار. 1 أموان أما ما يسمي بالإشتقاق الكبير فيفسر لنا عادة بأن بعض المجموعات الثالثية من أصيوات

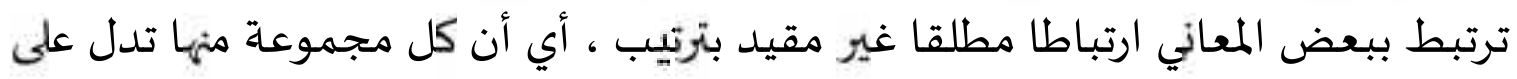

$$
\text { المعنى المرتبط بها كيفما اختلف ترتيب أصهواتها. }
$$

الكبير ويقصيد باه انتزاع كلمة من كلمة أخرى بتغيير في بعض حروفهيما مع تشاباه بينهما في المعنى واتفاق في الأحرف الثابتة، وفي مخارج الأحرف المتغيرة، وذلك نحو : جثا وحذا ، وبعثر

وبحثرث. 17

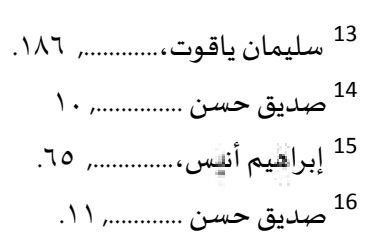


ويبدوا أن أصحاب الإشتقاق قد اقتبسوا فكرة تقلبات الأصيول من معجم "العين" , امثاله فقد سلك صاحب العين وصاحب الجمهور وغيرهما مسلكاعجيبا في تلرتيب الكلمات ، فكان كل منهم حين يعرض لشرح كلمة من الكلمات يذكر معها تقلباتها ، وبذكر معنى كل هل

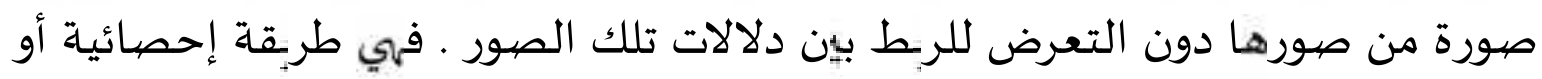
قسمة عقلية لجأ إلهها أصحاب هذه المعاجم بغية حصر كل كل المستعمل من كلمات اللغة ، وخشية أن يند بعضها عن أذهانهم . فلما جاء أصحاب الاشتقاق من أمثال ابن جني وابن منابه

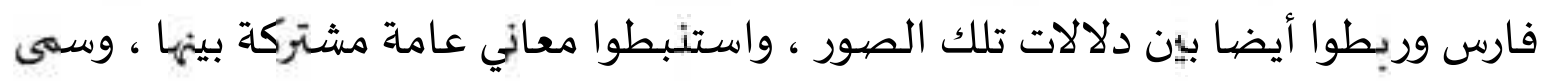
هذا بالإشتقاق الكبير. وبمثل له ابن جنى بعدة مجموعات لا يخلو معظمها من التكلف والتعسف والمس العلاقة

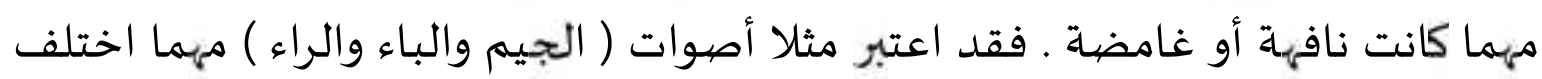

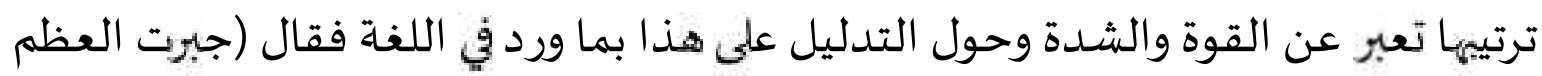

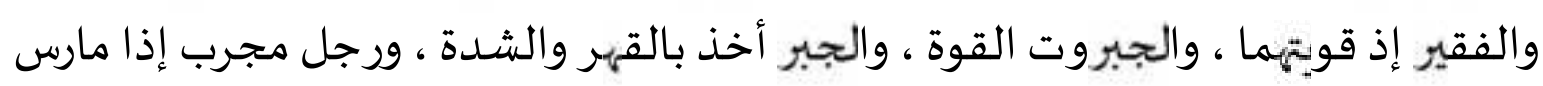

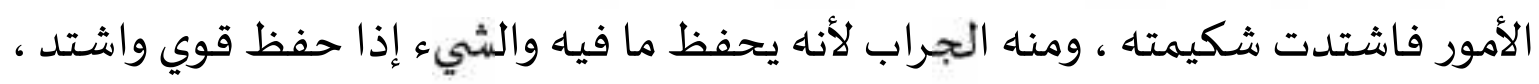

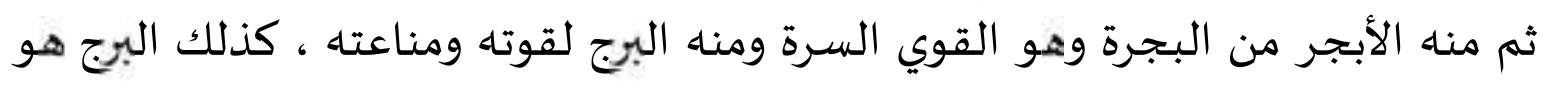

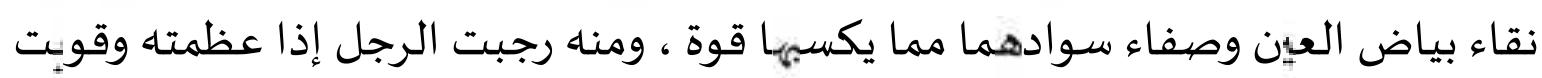

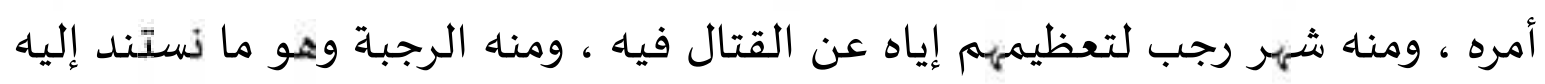
النخلة لتدعيهما وتقويتها. هكذا نرى أن ابن جني كان ممن يؤمنون إيمانا قويا بوجود الرابطة العقلية المنطقية

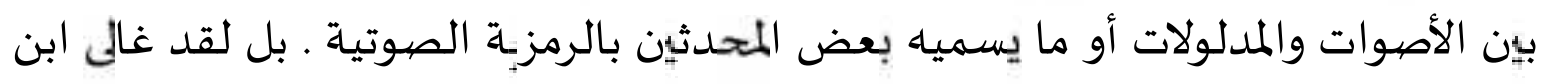

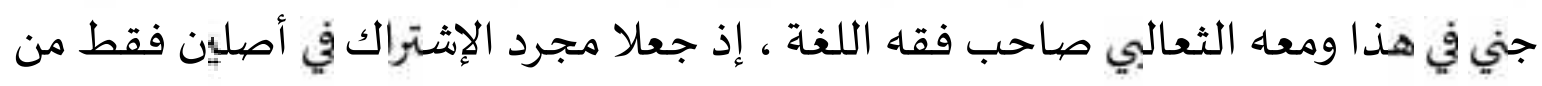

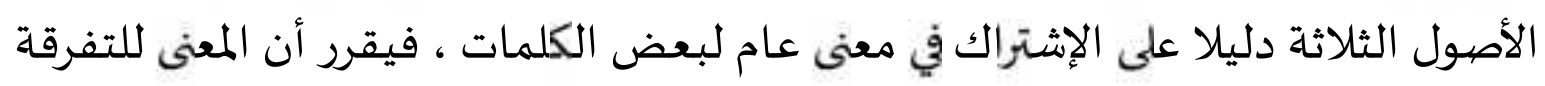

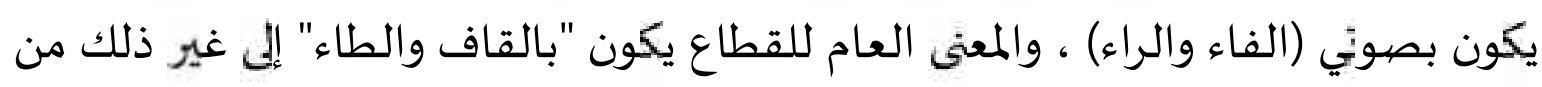

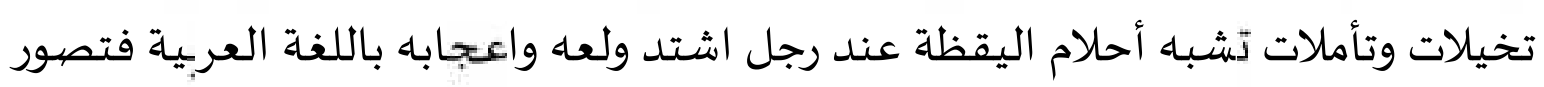

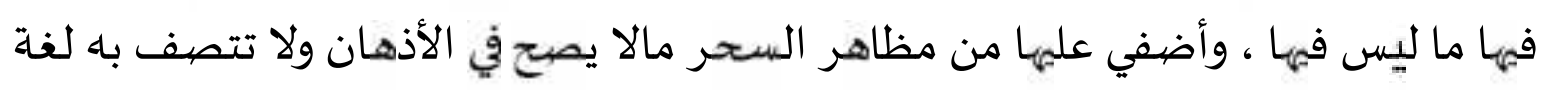
من لغات البشر. 
فإذا كان ابن جنى قد استطاع في مشقة وعنت أن يسوق لنا للبرهنة على ما يزعم

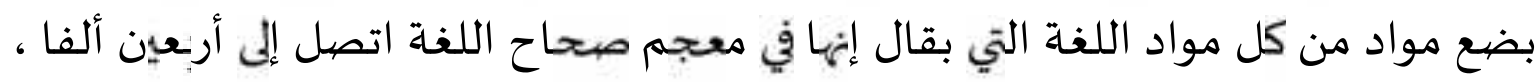
فليس يكفي مثل هذا القدر الضئيل المتكلف لإثبات ما يسمي بالإشتقاق الكبير. هذا وقد أورد السيوطي أمثلة أخرى للإشتقاق لا تدخل تحت هذا النوعين ، هذه الأمثلة التي ذكريا السيوطي أوحت لنا بتقسيم الإشتقاق إلى نوعين :

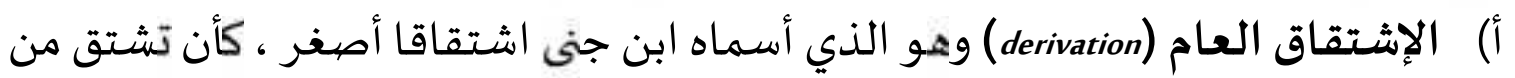
الكلمة اسم فاعل أو اسم مفعول أو اسم مكان أو صفة مشتهية وهو الإشتقاق المتعارف عليه مدرسيا.

ب) الإشتقاق التاريخي (etymology) وهو التتبع التاربخي لمعاني المشتقات من الكلمة الواحدة أو إرجاع معنى من المعاني إلى اشتقاقهاء من كلمة ما لعلاقة دلالية تجمع بينهما ، أو هو - كما تقول فندربس - "أخذ ألفاظ القاموس كلمة كلمة وتزويد كل واحدة منها بما يشباه أن يكون بطاقة شخصية يذطر فيها من أين جاءت ومتى وكيف صيغت والتقلبات التي مرت بها". والأمثلة التي ذطرها السيوطي وأوحت لنا بهذا التقسيم تدخل جميعها في نطاق القسم الثاني (etymology) ومنها: سميت (منى) بهذا الإسمر لما يعني فيها

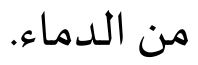

يقال ( شجرت فلان بالرمح) من الشجرة ، لأنك تجعله في الرمح كالغصن افي الشجرة ثادق : اسم فرس مشتق (ثدق المطر) إذا سال وانصب فهو ثادق. فكأن الفرس هذا في

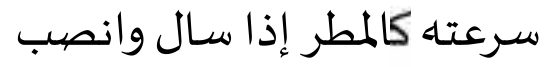
الثور : سمي بهذا الاسم لأناه يثير الأرض.

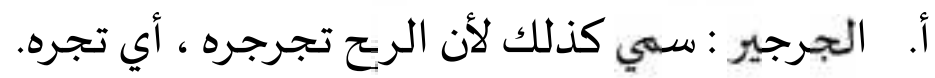
وقد ذكرفندربس مثالا لهذا النوع من الإشتقاق فرأى أن ماربشال وهي أكبر رتبة عسكرية إنما كان اشتقاقها من خادم الأصطبل في الألمانية القديمة

17 
r) الإشتقاق الكبار (النحت)

أما النوع الثالث من الإشتقاق وهو ما يسمي بالأكبر , ويمثل لله عادة بكلمات مثل (ازوهز .

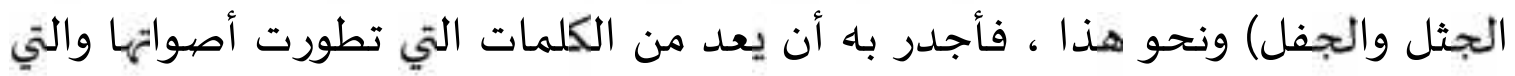
تبحث عادة في فصل القلب والإبدال، وهو ما سنعرض لله فيما بعد.`^(هو أن تنحت من كلمتين فأكثر كلمة لتدل على المعنى الذي نحتت مناه، كما ينحت النجار خشبتين

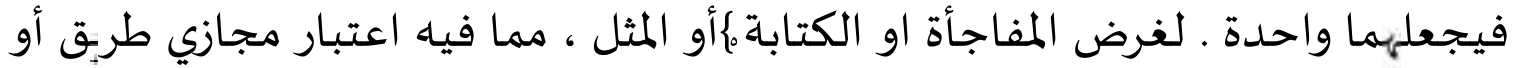
تعر:ض كما يقول الشيخ عبد الله العلايلي. أو لغرض السهولة اللفظية والإختصار والإختزال. وبـدل المنحوت على ماكانت تدل عليه الكلمة نفسها. وقد اعتبر بعض اللغوبين الاشتقاق والنحت تابعان من توابع القياس ، وذيلان له. وبعضيهم اعتبر النحت والزبادة

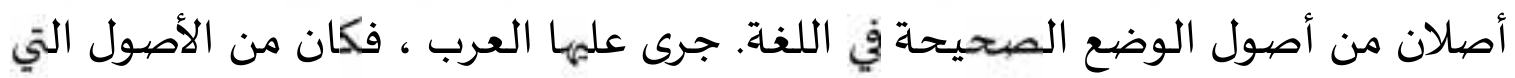
نمت اللغة. وسماه الأستاذ عبد الله أمين : الاشتقاق الكبار. وصرح الأستاذالأفغاني بأن : مرعاة معنى الاشتقاق تنصر جعل النحت نوعا مناه. ففي كل منهما توليد شيء من شيء. وفي كل منهما فرع وأصل. والفرق بينهما في اشتقاق كلمة من كلمتين أو أكثر على طربقة النحت، واشتقاق كلمة من كلمة في قياس التصريف.

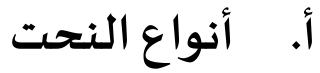

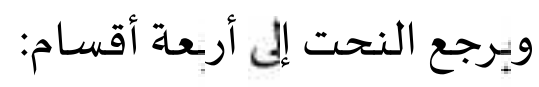

(1) نحت فعلي : بأن تنحت من الجملة فعلا يدل على النطق بها أوحدوث مضمونها ، مثل : بأبأ وجعفل وسمعل وبعثر وفذلك بمعنى (قال : بأبي أنت ، وجعلت فداك ، والسلام

$$
\text { عليكم، وب:عث وأثار ، وقال : فذلك العدد: قد بلغ كذا) }
$$

Y) النحت الوصفى : بأن تنحت من كلمتين كلمة واحدة تدل على صفة بمعناها، أو بأشد منها ، مثل : ضبطر (للرجل الشديد) من ضبط وضبر ، وصلدم (للشديد الحافر) من

$$
\text { صلدم وصيدم، وصيهصلق (لشـديد الأصروات من صهل وصلق) }
$$


r) النحت الإسمي : بأن تنحت من كلمتين اما مثل : جلمود للصخر القاسى) من جلد و جمد. وشطحب (للكبش العظيم) من شق الحطب.

ع) النحت النسبي : بأن تنحت من اسمين لتنسب إلى شخص أو إلى مدينة اسما واحدا . مثل : طهر ، خزى ، نسبة إلى (طبرستان ، وخوارزم ) وشفعنتي (نسبة إلى أبي حنيفة والشافعي). ب. أوجه النحت

على أن العرب لم تغل فيه غلوها في الاشتقاق ، وقلته -إن صع هذا - لا تنفى

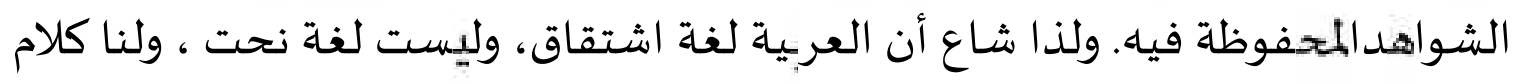

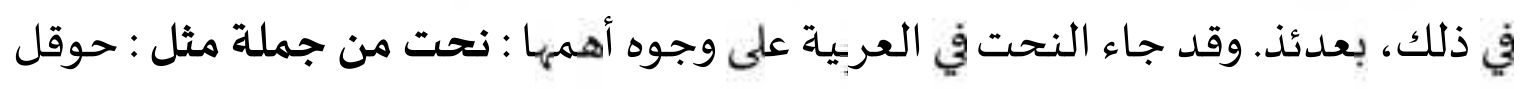

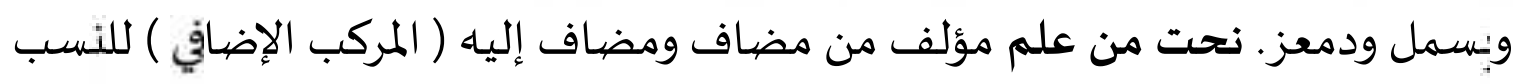

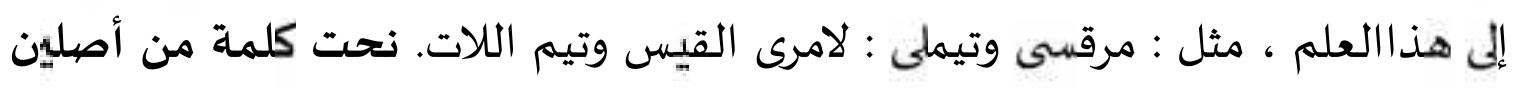

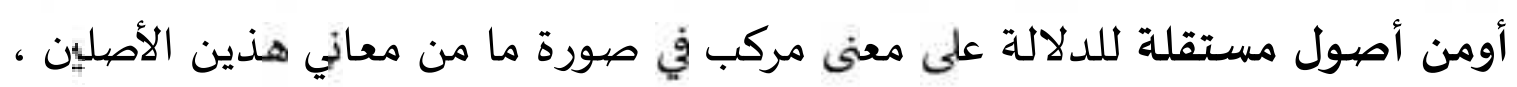

أوهذه الأصيول.r أومن اهول

\section{0) الإشتقاق الشعبي}

الإشتقاق الشعبي (volksetymologie) للكلمة معناه : المفهوم الشعبي عند العامة لكلمة من الكلمات ، بربطها بكلمة أخرى شائعة ، والظن بأنها مشتقة من هذه الكلمة ، أو كما

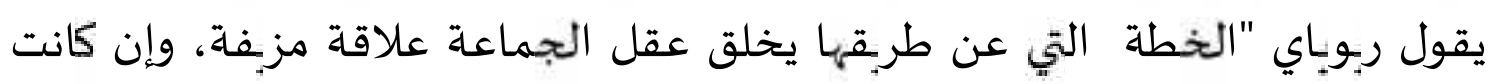

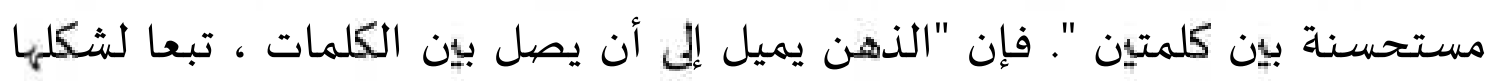
الخارجي ، وأحيانا على عكس ما يقتضي المعنى ، بل على عكس ما يقتضي العقل السليم

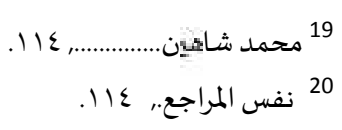


، وقد تسوق مشابهة غامضية ، بين كلمة وكلمة أخرى أشـد شيوعا ، أو أكثر شهوة ، إلى التقربب بينهما ـ ومن هنا تنشأ بعض التشويها الغربية.

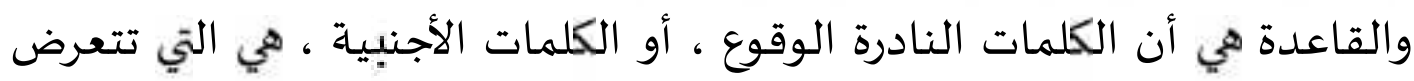

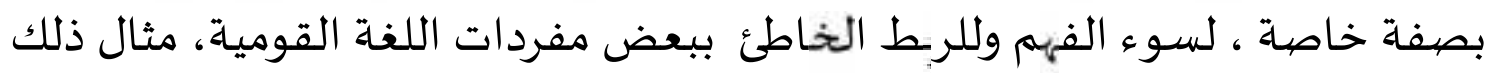

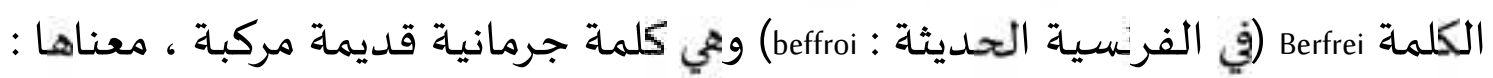
"البرج يحتمي به". ويرجع السبب في وجود حرف اللام فهها. وكذا السبب في معناها

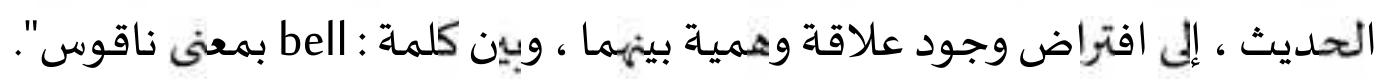

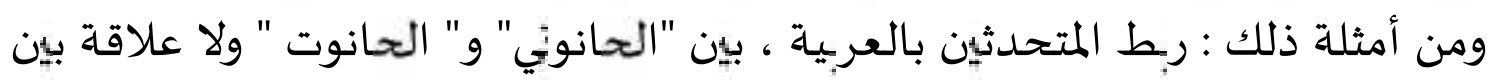

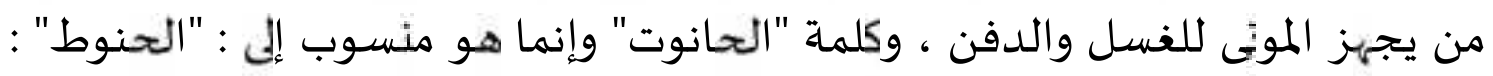

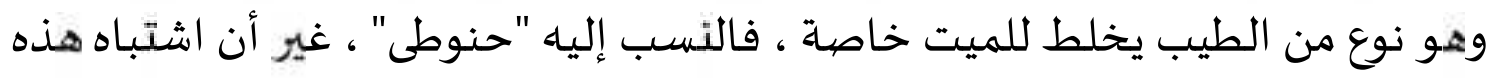
الكلمة صوتيا بكلمة "حانوت" هو الذي أدي إلى هذه الإشتقاق الشعبي.

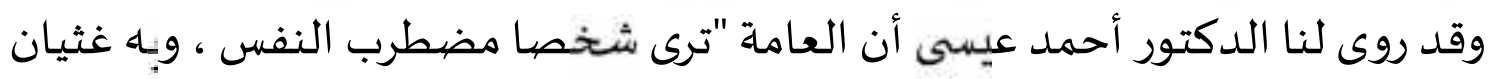

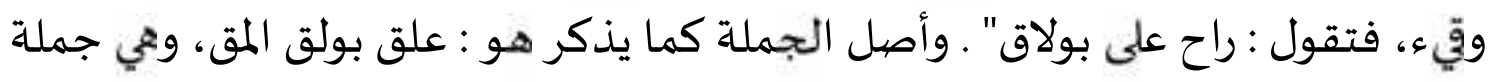

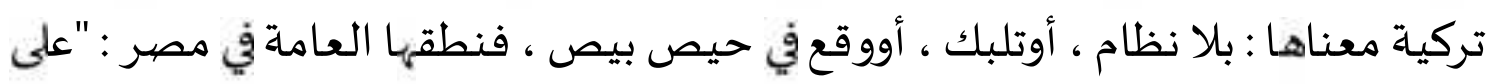
بولاق" وهو من الإشتقاق الشعبي. وإذا كانت المعاجم العربية تذكر : "الحندور", على أنها حدقة العين . فهمنا الإشتقاق



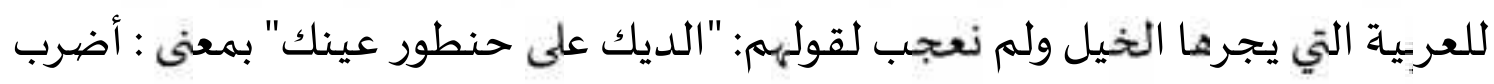
حداقة عينك".

وكادت امرأة مصرية حاسرة الرأس ، تتشاجر مع خادم مسجد الكاظمين ببغداد ، عندما

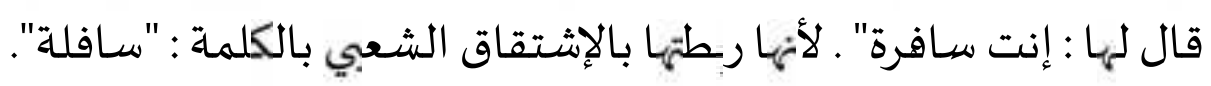
وكان أحد الألمان يصف الجو بالبرودة بقوله بألمانية :kalt أمام أخذ الإخوة العراقيين ، وكان قد فرغ في التو من الأكل في المطعم بألمانيا. فرد عليه العراق قائلا :

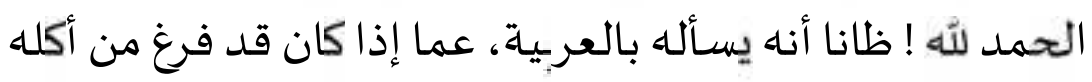


وقد حكي لي الدكتور عبد الوهاب التازي ، أن بعض المغار.ة يطلقون على طائر اللقلق

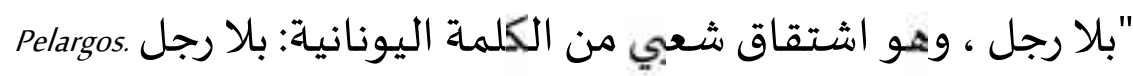

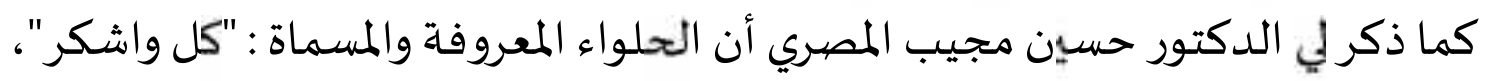

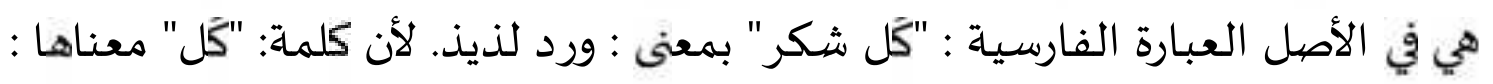
ورد ، وكلمة : شكر سكر. وهذا هاةو الإشتقاق الشعبي عند العوام.

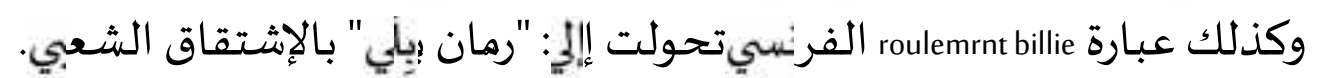
كما روي لي بعض العراقيين أن العامة في بغداد، ينطقون كلمة "برفسور" ب"برفيصيل وهذا أيضا من الإشتقاق الشعبي. ومن أمثلة ذلك في عربية العصري العباسي: استخدام

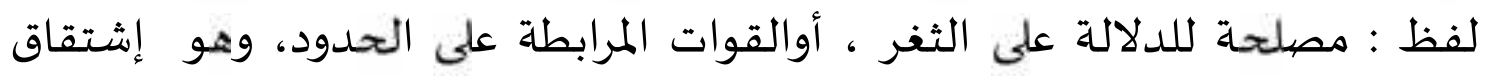

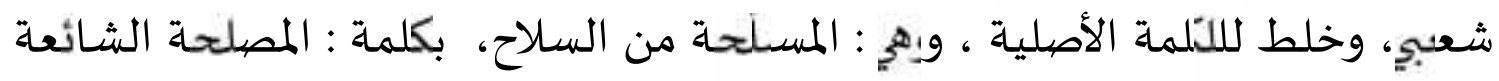
بمعنى : المطلب أو المنفعة وحية

ولو أننا نظرنا إلي عبارة : لقمة القاضي ، وهي تلك الحلوى من عجين وسكر مذاب ،

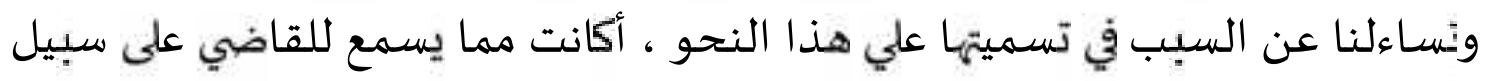

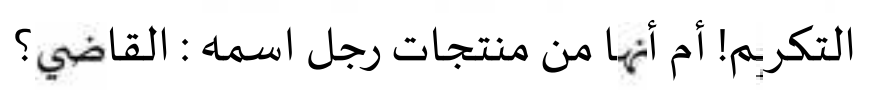
"لا هذا ولا ذاك ، ولكن الأتراك في مصر كانوا يسمونها : (لقمة القادين)، وكلمة: قادين تعني السيدة ، أو المرأة في تركية ، ولا شك أن من سمات الجمل ، أن يكون فم المرأة

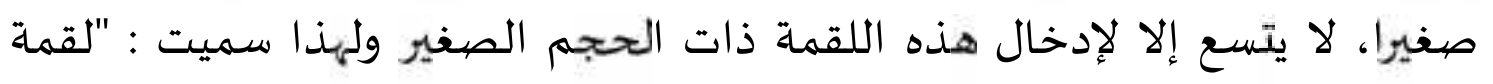
القادين" ولنأخذ مثلا آخر ، على مثل هذا التحربف السماعي على ألسنة العوام. فالوقاد الذي (كان) يعمل في القطار (البخاري) لتزويده دائما بالوقود والنار، يسمي في مئي

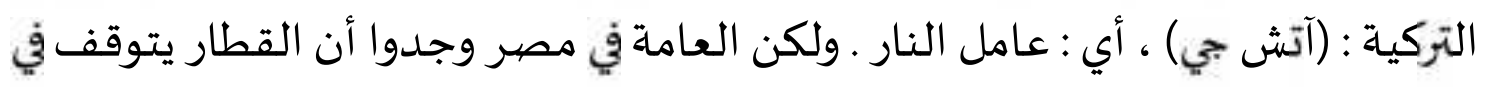

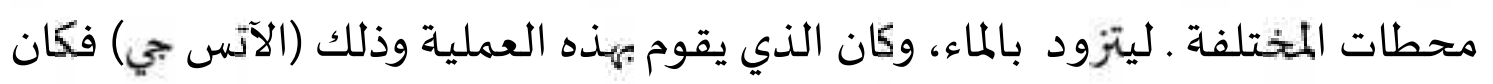

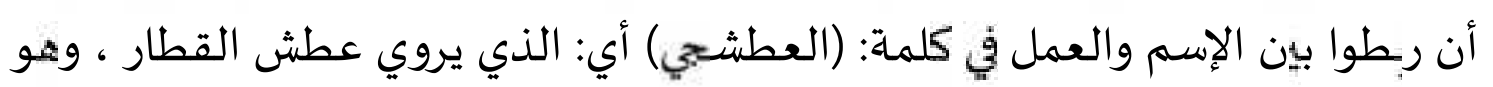
نوع من التقربب بين الكتلة الصوتية والمدلول الظاهر. 
وهذه الظاهرة تشيع بين الأطفال ، ذوي الخبرات اللغوبة المحدودة ، فقد سمعت

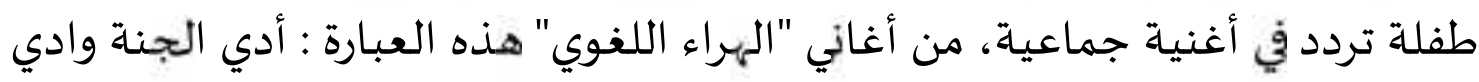

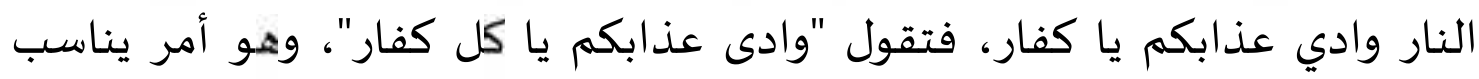
الحصيلة اللغوية لمن في مثل سنها. وقد ضرب لنا فندربس، أمثلة كثيرة لهذه الظاهرة من اللغات المختلفة فذكر أن "التسمية courte pointe ومعناها الحرفي : ملحفاة ذات غرز ، صلاتينية : culcita puncta

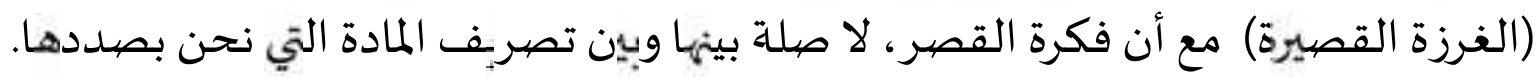
والرقص الإنجليزي المسمى countrydance (رقص الر:ف)مع أنه منقول من فرنسيا، دخل اسماه في اللغة الفريسية من جديد بصيغة countredanse (عكس الرقص) وعي عبارة لا معنى لها. ونحن نعرف الصيخ المعرفة، التي تأخذها أسماء الأمراض والأدواء والعصيية، في أفواه اهدياه العامة فهي كنز لا يفنى من التسلية، للمشتغلين بتسجيل الطرائف.... ومن أمتع هذه

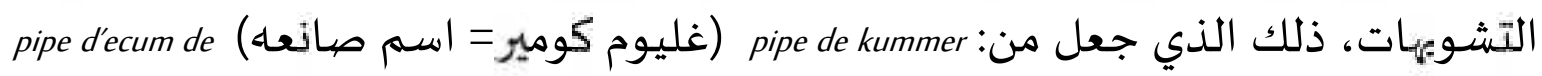
mer

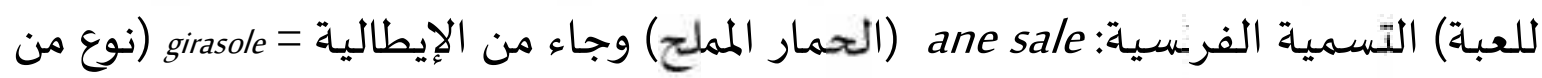
الخضروات) الكلمة الإنجليزية: Jerussalem اسما لهذا النوع من الخضروات" وقد شبهاه

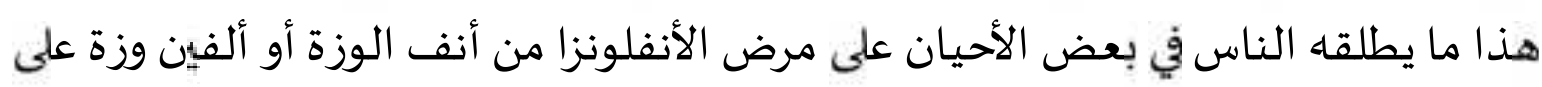

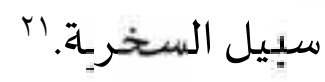

$$
\begin{aligned}
& \text { ج. تعليم المفردات } \\
& \text { (1) مفهوم المفردات }
\end{aligned}
$$

المفردات إحدى العناصر اللغوية. هي أدوات حمل المعنى كوسيلة للتفكير، لأن المتكلم

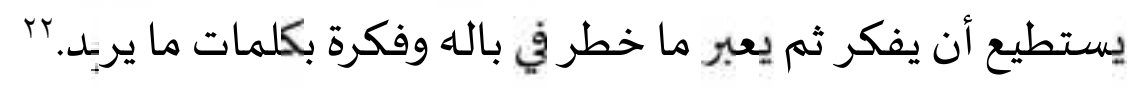

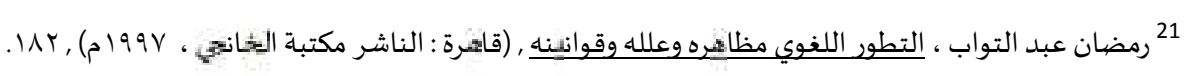

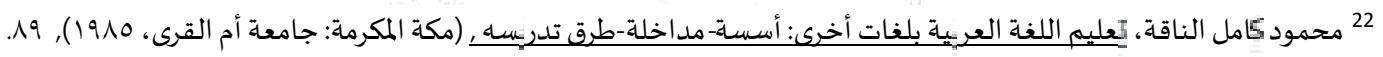


المفردات يسمى بالكلمات، وعي أصغر وحدة لغوية حرة. مثلها كلمة (استعلم) و(يوم) و(إلى). وقد تكون المفردات مجردة وتكون مزبدة. فإن كانت مزبدة فلهيا جذر وبها زائدة واحدة أو أكثر. فكلمة (استعلم) جذرها (علم)، وأما زائدة فيها فهي الهمزة والسين والتاء. والزائدة قد تكون في أول الكلمة فتسمى سابقة، مثل (است) في (استقدم). وقد تكون الزائدة في وسط الكلمة، فتدعى داخلة، مثل الألف في (قادم). وقد تكون الزائدة في آخر الخر

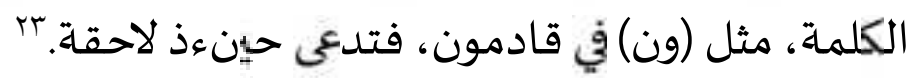

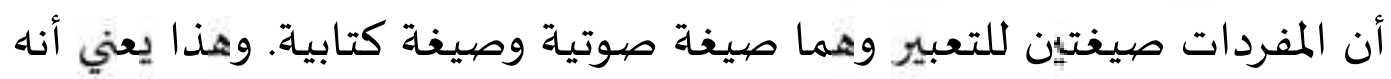
حين نعلم الطالب كلمة جديدة فعلينا أن نعلماه كيف ينطقها نطقا صحيحا وكيف يكتها كتابة صحيحة. بالإضافة إلى ذلك، فإن للمفردات صيغة صرفياة تدل عليها. فالفعل له

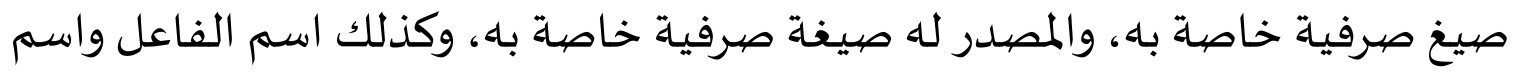

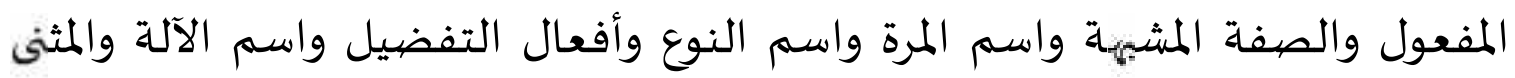

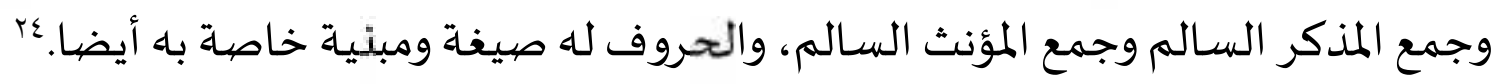

\section{r}

عادة تعليم المفردات للطلبة الأجنبية يقاس على قدرة الطلبة في ترجمة الكلمة وتحديد معنى المفردات ونطقها السليم، واستخدام الكلمة المناسبة في سياق الجملة السليمة. ويعتبر بعض اللغويين أن حفظ الطلبة للمفردات العريية عملا غير علمي، إذ أربد تقويم قدرة الطلبة لمعرفة قدرنهم اللغوية على المدرس أن يعد البرنامج يمكن عليهم

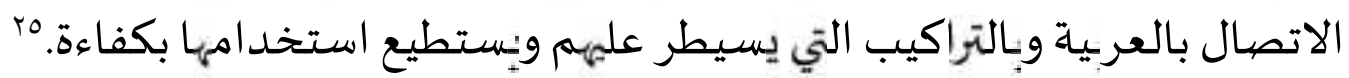

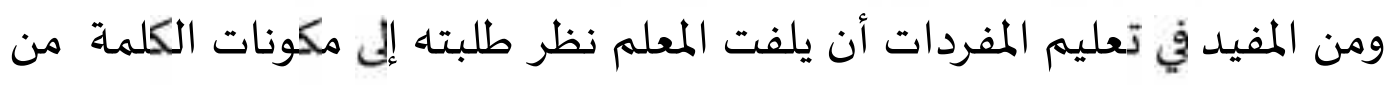

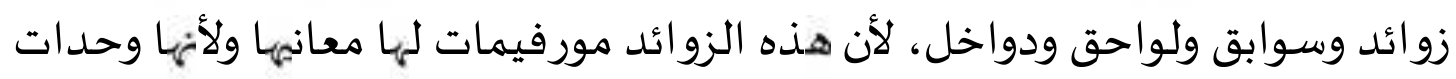
يكثر تواجدها في كلمات الللغة. فإذا فههم الطالب معناها سهل ودواهل عليه أن يفهه معنى 
الكلمات التي تتواجد فيها وخاصية إذا فهه معنى الجذر. ولابد بالطبع من مراعاة

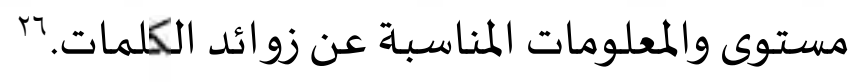

$$
\begin{aligned}
& \text { د. أسس اختيار المفردات } \\
& \text { أسس تعتمد في اختيار المفردات الآتية: } \\
& \text { () الشسيوع }
\end{aligned}
$$

فضلت الكلمة شـائعة وواسعة الاستخدام والكلمة التي يحتاج إلهها الطلبة أكثر على غ يرهها ما دامت متفقة في المعنى. وهذه من الأسس التي تتعلق بثقافة الدارسين. (r) (ب التوزع

تفضل الكلمة التي المستعملة في كل البلاد العربية على الشائعة في بعضها. تقديم الكلمة

$$
\begin{aligned}
& \text { دراجة بخاربة من جوالة. } \\
& \text { r) المتاحية }
\end{aligned}
$$

تفضل الكلمة التي تكون في متناول الفرد يجدها حين يطلها والتي تودي له معنى محددا وبقاس هذا بسؤال الناس عن الكلمات التي يستخدمونها في مجالات معينة. تقديم الكلمة أكل قبل ناقش. ع) ع الألفة

تفضل الكلمة التي تكون مألوفة عند الأفراد على الكلمة المهجبورة نادرة الاستخدام مثل تقديم شمس من ذكاء. 0) الشمول

تفضل الكلمة تعطي أكثر من مجال عن المحصيورة في مجال أو لا تخدم إلا مجالات محدودة، تقديم بيت من منزل. 


\section{1) العروبة}

تفضل الكلمة العربية على غيرها. فإذا لم توجد كلماة عربياة تفضل الكلمة المربة مثل الهاتف على التليفون.

\section{ذ. تعليم المفردات في الاشتقاق وخطوات لتعليم المفردات له}

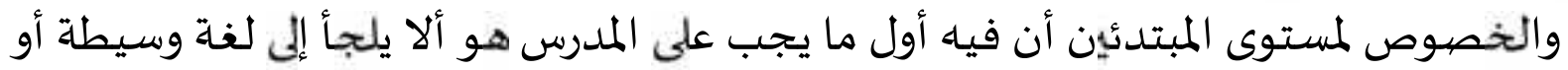

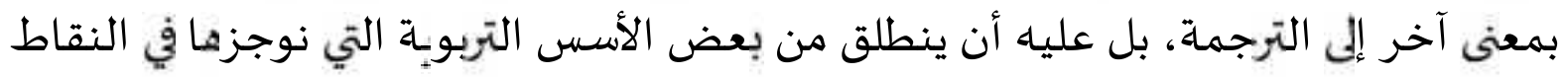

1) إذا كان الطلبة في المستوى الأولى، على المدرس أن يقتصد في المفردات التي يستعملها وأن يقلل من كلامه قدر المستطاع، فحصيلة الطلبة من المفردات ضيئلة ولا فائدة من إغراقههم في سيل من المفردات التي لا يفهمون منها شيئا، عليه أن يستعمل من الألفاظ ما

$$
\text { يلزم فقط وما يحتاجهاء في مهمتاه. }
$$

Y) والمدرس ممثل وهذا لا يعني أنه ينبغي فقط أن يستعمل الحركة، وإنما ينبغي أيضيا أن

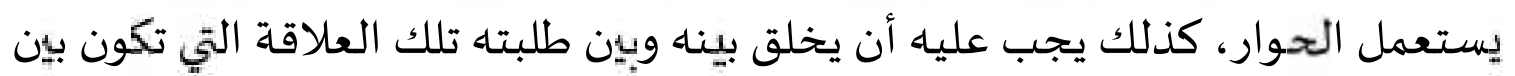
الممثل والجمهور، علياء بطيعة قائما لأنها هو وحده الذي يثير الاهتمام.

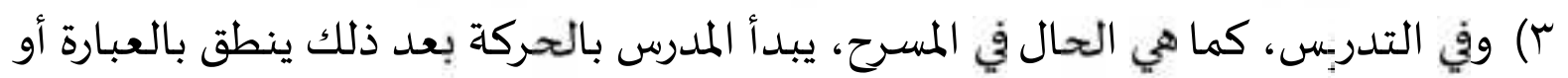
الجملة ثم يطلب الطلبة ترديدها فرديا وجمعيا. ع) والتدرج من السهيل إلى الصعب. 0) واختار المدرس عن المفردات من السهلة، ولكل المفردات يستطيع المدرس أن يفرع حسب

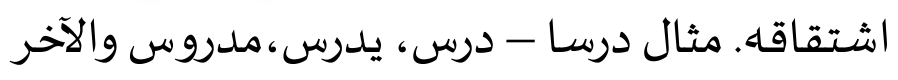

7) أما بالنسبة للموضوعات فإن غالبة كتب تعليم اللغات للأجانب المبتدئين تدور

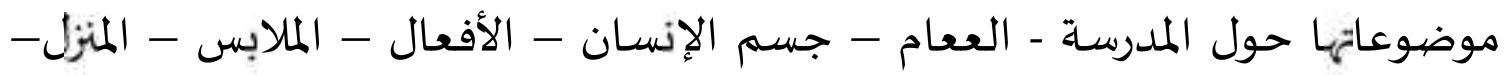

$$
\text { الأسرة - الدين - الرحلات - الرباضية. }
$$

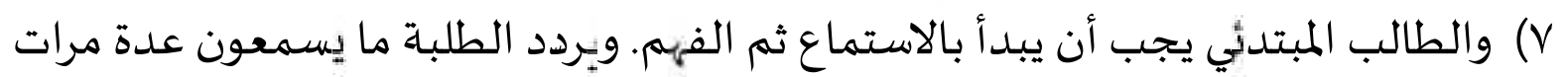

$$
\text { وعلى المدرس يلاحظ النطق ويقوم بالتقويمه. }
$$


^) ولكي يكون الدرس حيا يجب أن يكون في شكل الحوار، والكتاب مغلوق عن طر:ق السؤال

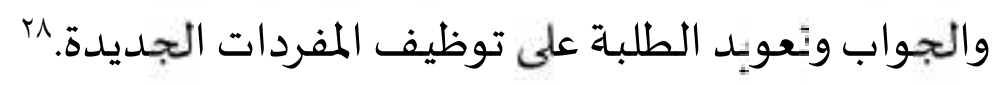

ثم يوصل المدرس تدريس المفردات بالنطق حتى تمام اكتساب المفردات شفويا

فعلى المدرس أن ينطق ما يكتب. وبحتاج الطلبة إلى تثبيت المفردات المكتسبة

واستظهارها، ثم إلى الانتقال بها من مرحلة السلب إلى الايجاب، وهنا نقترح عدة أسـالب:

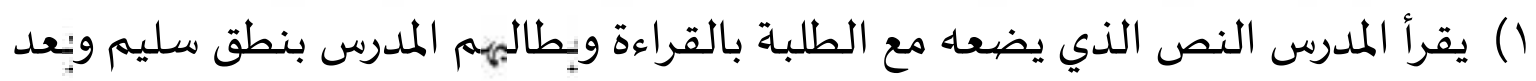

ذلك تجري مناقشـة النص، تتلوها مناقشة أخرى قربية منها.

r) يطلب المدرس من الطلبة تكوين جمل حول المفردات المكتسبة، ويقوم الطلبة بتوجياه

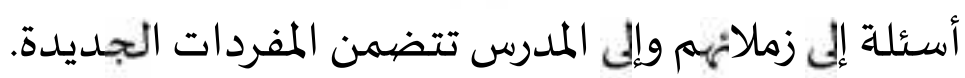

r) يعطي المدرس بعض التمربنات التحربر:بة لمراجعة العناصر المدروسة.

ع) ونتعتبر الإملاء تمربنا ممتازا لمراجعة فهم الطلبة والتأكد من استيعابهم.

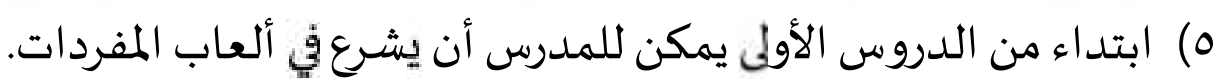

وهذه إحدى من الخطوات لتعليم هذه المفردات:

7) ينطق المدرس الكلمة و الطلبة يستمعون. ومن الأفضل أن يكررها مرتين أو ثلاثا.

V يكتب المدرس الكلمة على اللوح مشكولة شكلا كاملا.

( ) يعرض المدرس معنى الكلمة بالطربقة التي يراها مناسبة.

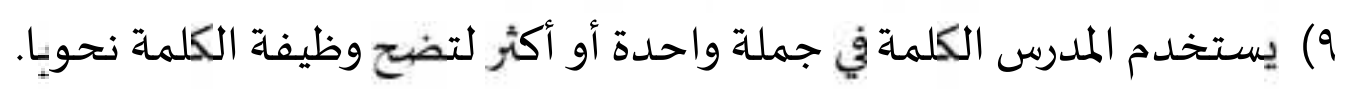

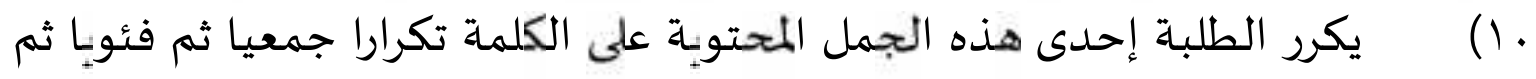
فرديا.

يلفت المدرس نظر الطلبة إلى الطربقة كتابة الكلمة إذا كانت تنطوي على

$$
\text { صعوبات إملائية. }
$$

يكتب المدرس على اللوح معنى الكلمةة، كما يكتب جملة تبين استخدام الكلمة.

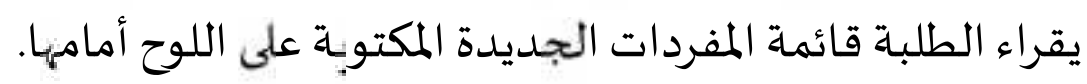

يكتب الطلبة الكلمات ومعانيها والجمل التوضيحية في دفاترهم.

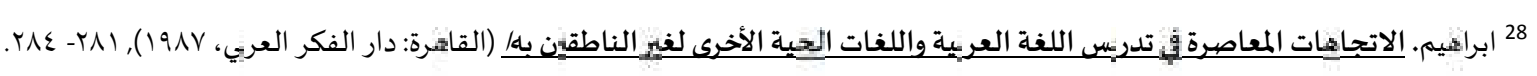


ر. الخاتمة

فخلاصة هذا البحث هي أن علم الإشتقاق هو علم باحث عن كيفية خروج الكلم بعضها عن بعض بسبب مناسبة بين المخرج والخارج بالأصالة والفرعية باعتبار جوهرها ، والقيد الأخير يخرج علم الصرف إذ بحث فيا أيضا عن الأصالة والفرعية بين الكلم لكن لابحسب الجوهرية بل بحسب الهيئة، مثلا يبحث في الإشتقاق عن مناسبة "هنق" و "نعق" بحسب المادة ، وفي علم الصرف عن مناسبة بحسب الهيئة فقط، فامتاز أحدهما عن الآخر واندفع توهم الاتحاد.

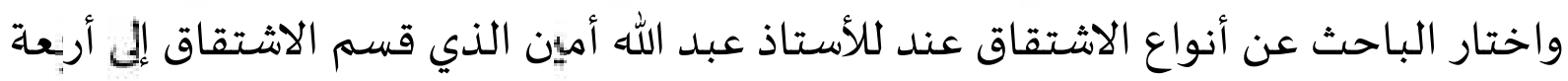
أقسام التي ألفت كتاب الاشتقاق من الدراسات الحديثة. واختلف بين القدماء والحديث في الحيتهاف نوع الاشتقاق الكبار أو النحت. ومن خطوات تدربس المفردات في الاشتقاق هي : التمهيد ، نطق المفردات، المفردات واشتقاقها. 


\section{المراجع}

أحمد سليمان ياقوت ، أبحاث في اللغة (الاسكندربة : دار المعرفة الجامعية ، ع ع 99 م)

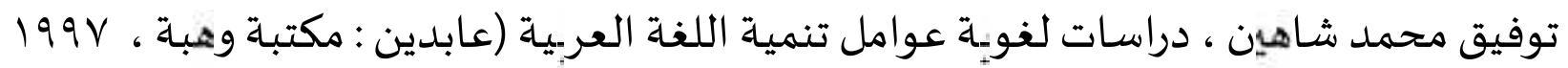

محمد صديق حسن خان ، الخفاق من علم الإشتقاق (لبنان : مؤسسة الكتب ثقافية ، و9 19 م)

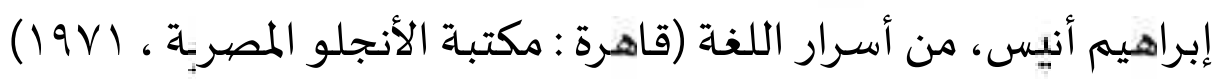

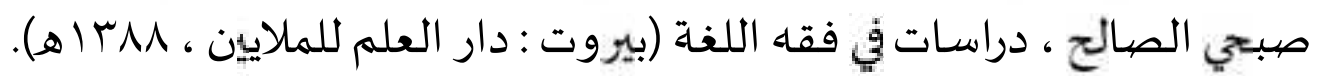

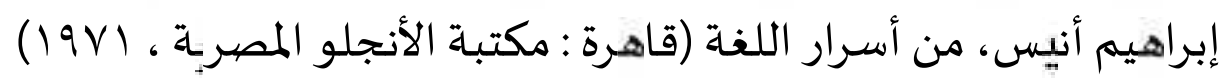

رمضان عبد التواب ، التطور اللغوي مظاهره وعلله وقوانينه (قاهرة : الناشر مكتبة الخانجي ، (م) $199 \mathrm{~V}$

محمود كامل الناقة، تعليم اللغة العربية بلغات أخرى: أسسة-مداخلة-طرق تدربسـه (مكة

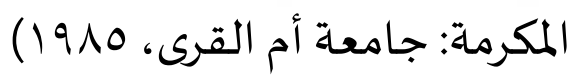

محمد حلي الخولي، أساليب تدربس اللغة العريية (الرباض: حقوق الطبع محفوظة للمؤلف، $(19 \vee 9$

رشدي أحمد طعيمة، تعليم العربية لغير الناطقين بها مناهجة وأسـاليبه/ (مصر: إيكسو، $(1919$

ابراهيم. الاتجاهات المعاصرة في تدربس اللغة العربية واللغات الحية الأخرى لغير الناطقين بها (القاهرة: دار الفكر العربي، I9NV) 